was treated with the kernel of the atun tree, these kernels were described nearly 400 years ago as a treatment for symptoms that are treated today with modern antibiotics. The current literature has no descriptions of the use of the atun tree to treat any disease similar to dysentery. ${ }^{6}$ By searching historical texts on herbal medicine, therefore, we have identified a potential new drug with antibacterial properties and have recovered lost knowledge of traditional medicine.

We thank Timothy Motley, Old Dominion University, USA for suggesting Independent Samoa as the location for the botanical expedition and Robin Patel, Mayo Clinic, USA for providing the bacterial samples.

Contributors and sources: EJB conceived the study, drafted the manuscript, and helped in its design and coordination. $\mathrm{BAB}$ helped design and coordinate the study. HEJ and GT helped in the botanical field work and creation of the voucher specimens EMB translated the historical text and helped draft the manuscript. KLF assisted with the minimal inhibitory concentration assays. CLH helped in study design and statistical analyses. All authors read and approved the final manuscript. EJB is guarantor.

Funding: None.

Competing interests: Since this manuscript was accepted, Mayo Clinic has applied to patent the antibacterial properties of the atun tree. $\mathrm{BAB}$ and $\mathrm{EJB}$ are on the patent. The patent was only recently submitted so we do not know its status.

1 Riddle JM. History as a tool in identifying "new" old drugs. $A d v$ Exp Med Biol 2002;505:89-94.

2 Buenz EJ, Schnepple DJ, Bauer BA, Elkin PL, Riddle JM, Motley TJ. Techniques: bioprospecting historical herbal texts by hunting for new leads in old tomes. Trends Pharmacol Sci 2004;25:494-8.

3 Buenz EJ, Johnson HE, Beekman EM, Motley TJ, Bauer BA. Bioprospecting Rumphius's Ambonese herbal: volume I. I Ethnopharmacol 2005:96:57-70.

4 Rumphius G. Herbarium amboinense. Amsterdam: Uytwerf, 1741-55.

5 National Committee for Clinical Laboratory Standards. Methods for dilution antimicrobial susceptibility tests for bacteria that grow aerobically. 6 th ed. Wayne, PA: NCCLS, 2003.

6 Prance G. The uses of Atuna racemosa Raf. (Chrysobalanaceae) in Samoa. Econ Bot 2004;58:470-5

(Accepted 10 March 2006)

doi 10.1136/bmj.39008.492361.BE

\section{The life of G E Rumphius}

Georg Everhard Rumpf (fig 2)-who Latinised his name to "Rumphius" after he achieved renown as a naturalist-enlisted as a soldier in 1652 with the first multinational corporation of the modern era, the Dutch East India Company. In 1657 Rumphius was discharged from the military to the civilian branch of the company, and he started to collect, describe, and draw the plants for his monumental Ambonese Herbal.

It is amazing that Rumphius's work was ever published. In 1670 he went blind, and four years later his wife and daughter were killed in an earthquake. Thirteen years later, in 1687, a fire levelled the capital of Ambon's European quarter, and his manuscripts and the botanical illustrations that he had drawn himself were burnt. Yet Rumphius took this opportunity to begin the herbal again; he dictated a new and revised text in Dutch to scribes, and he commissioned draftsmen to do the illustrations.

Finally, in 1692, the first half of the Ambonese Herbal was finished, and the governor general at the time ordered the manuscript and the illustrations to be copied. This order was fortunate, as the original herbal text was destroyed on the way to Holland when the transport ship was sunk by a hostile French naval squadron. Again, upon notification of the disaster Rumphius did not surrender to despair. Rather, he took the opportunity to augment and correct the first half of his text while he completed the six volumes of the second half. Rumphius added new material (to make volume seven) only a few months before his death at the age of 74 .

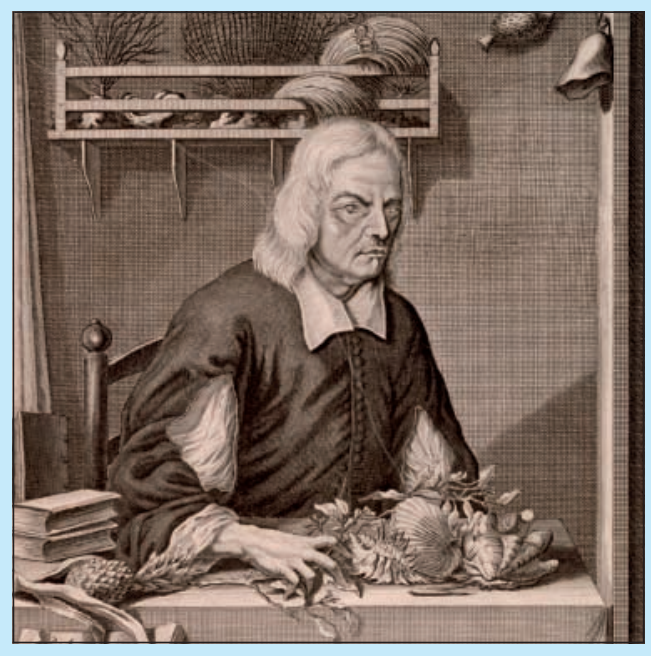

Fig 2 G E Rumphius, who spent most of his life documenting the medicinal uses of plants on the island of Ambon in Indonesia

\title{
Getting new drugs to market: how individuals could do this without leaving their desks
}

\author{
Joe Collier
}

At one time, all of the products that came out of a pharmaceutical company were researched, devised, developed, and manufactured within its four walls; the company offered the complete package. Now, although vast amounts of money, intellectual property, and management capacity remain within the imposing headquarters of the multinationals, much of the real work is done elsewhere-by start-up companies, contract houses, university departments, and public bodies.

One way or another, the work of big drug companies has changed, and inevitably this change, which will continue and probably accelerate, will lead to the collapse of the monolithic system and its replacement by smaller, leaner, and more nimble companies. As this process continues, virtual companies, run by individuals working from their desks in cyberspace, could well develop.

\section{Developing drugs}

The development of medicines for human use is a tricky business and one that is continually evolving as new technologies, such as genetic engineering, emerge. At its simplest, the process involves finding "new" molecules, purifying them, checking that they do what they are designed to do, showing that they work in 


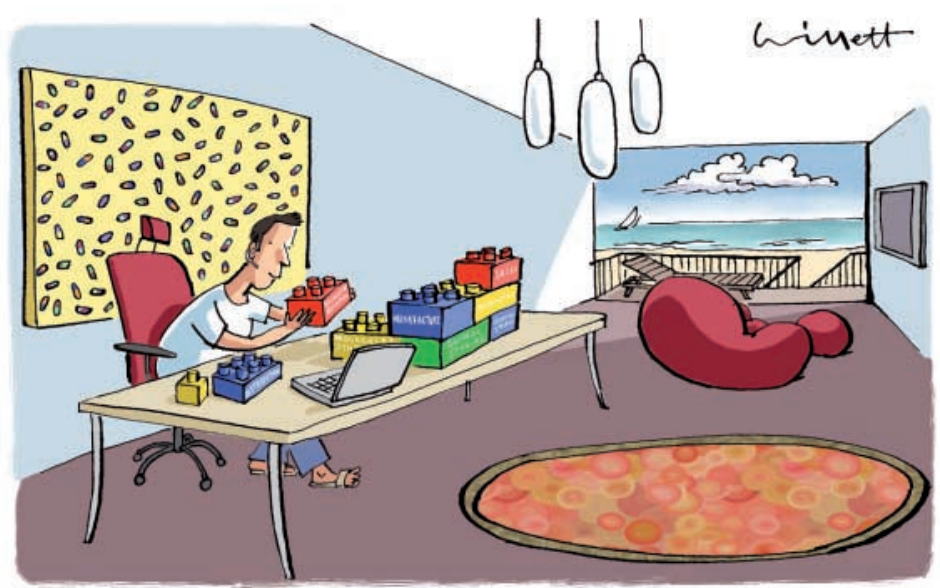

clinical practice without causing unacceptable harm, and then scaling up their manufacture to make the product of acceptable quality in commercial amounts. Along the line the product needs to pass legal hurdles to allow it to be sold and marketed to ensure returns. All of these steps, some running simultaneously, take time (currently 10-12 years), need money (estimated as being between $\$ 500 \mathrm{~m}$ and $\$ 800 \mathrm{~m}^{1}$ ), and require careful coordination.

These steps consist of discrete packages of work relating to, for example, molecule synthesis, target validation, animal efficacy, animal toxicology, animal and human pharmocokinetics and pharmacodynamics, teratogenicity, carcinogenicity, effects in patients (clinical trials through phases I-IV), drug side effects, and drug interactions. Added to these are applications for patents and regulatory approval, followed by product manufacture, marketing, promotion, distribution, sales, and supply.

Each of these discrete packages can be (and is being) undertaken, or managed by, small and highly skilled independent companies. In some instances, as with start-up companies, small groups develop ideas and products and then sell, or license, them on to the larger companies (the antiflu drug zanamivir was discovered by a biotech company in Australia, then licensed to GlaxoWellcome ultimately to be marketed as Relenza). In other instances larger companies will contract out work, for instance to public relations companies who will be in charge of marketing their products, or to development companies who will undertake clinical trials. So, for instance, the website for advertising agency McCann Erickson (www.mccann.co.uk) tells that it is their philosophy to "single out your story from the crowded advertising page, endow it with the gift of vitality, create from it the buying impulse" and the contract research house Quintiles (http://quintiles.com) states that for clinical research work "we have global resources to quickly assemble not just a project team, but the best project team for local studies or multi-country mega-studies." In some instances the drug companies expressly set up arrangements designed to court those with new ideas so that the two can develop new products to mutual advantage, for example the GlaxoSmithKline Centre of Excellence for External Drug Discovery (www.ceedd.com).

This notion of contracting in or contracting out work is part of the pattern of how drug companies are now working. If the contracting business can work for drug companies, why not for an individual entrepreneur acting as a virtual company? Moreover, if the key features that make the big drug companies "tick" are centred primarily on their financial and intellectual resources, then perhaps an entrepreneur with an interest in health would be a welcome change. After all, it is the drug industry's obsession with secrecy (a position that will serve to guard its intellectual resources) and its excessive pricing (a strategy designed to protect its wealth), that make drug companies particularly unpopular. It is also these assets (money and information) that give the industry its power and influence.

We have to assume that the changes in drug development have come about for some reason, rather than being the product of chance. We do know that the large (multinational) drug companies are bulky, cumbersome, and costly to run and that they have, at least in the recent past, failed to produce the new products needed to guarantee returns, and have appeared (or have chosen to be) sluggish as often they have left the initiative and risk for new advances, particularly of biological agents, to small highly specialised biotech companies. Also, companies have a poor image and a high level of distrust. The collapse of the old system, at least as it relates to producing new drugs for the developing world, is echoed in the comment by Daniel Vasella, chief executive officer of Novartis, that "We have no model which would [meet] the need for new drugs in a sustainable way" and if you want drug companies to systematically invest in this area, you will "need a different system." Even the large drug companies seem to recognise the need for change; now, with a myriad of independent contract houses, the wherewithal for change is in place.

\section{What would an individual need to do?}

It would probably cost around $\$ 150 \mathrm{~m}-\$ 240 \mathrm{~m}$ to bring a new drug to market if the project is well managed, ${ }^{1}$ so the head of the virtual company will need to have access to such funds, sustained over 10-12 years. Stepwise development with support from seed investors, then venture investors, and then institutional investors would probably be the wisest approach and would share the risk, but investors, like drug companies themselves, will not spend their money unless they feel secure about returns.

Assuming the money was there, entrepreneurs would need to surround themselves with a successful team (the members of the virtual company). The head of one large multinational is purported to have claimed that with 20 or so of his senior (and handpicked) colleagues he could run a company with ease. In addition to the chief executive, the members of the virtual company would probably need to include a talented senior scientist, researcher, financier, accountant, administrator, clinician, chemist, lawyer, marketeer, information technologist, and manager. Moreover a core of the team would need to know its way around the industry, academia, and the regulatory business. Clearly the team would need to understand drug development and the processes involved in "contracting" work. Somehow the new virtual company would probably need to develop a "persona" with an agreed modus operandi, qualities that the big drug companies 
see as particularly important. The company could be profit led (any drug would do, provided it raised money), disease led (focusing on drugs that target a particular disease, tuberculosis perhaps), or drug led (developing biotech products, or drugs from products now used as folk or herbal medicines, for example).

\section{What might be the advantages or disadvantages of the virtual company?}

The drug industry is made up of a few vast companies which reside in definable and tangible bases ("homes"), which, by and large, have identity, stability (staying power capable of long term investments), and familiarity (including their foibles); they tend to produce perhaps dozens of drugs, have a vast science base, have an unsurpassed worldwide sales network, and have some shared understanding with both doctors and society at large. Over the years the roles and responsibilities of drug companies have been defined in law and practice, as have their financial arrangements (public company status), which bring with them the openness (albeit limited) that the business world demands.
Virtual companies would be very different. Gone would be any dividend arising out of stability and familiarity, any advantage from having a dedicated science force working to a recognised process, any insights arising from any shared understanding, and we could find ourselves dealing with a myriad new companies producing only a few products. In the new order, society would have to revise the ways it might influence the companies. Instead of lobbying shareholders and the financial sector, we would, for instance, have to lobby the venture capitalist, and this would require new insights and understanding. But in return, a more dynamic and imaginative drug producing process could result, the overpowering and stifling influence of drug companies on governments and policy makers would be lifted, and the price of medicines should fall.

\section{Competing interests: None declared.}

1 Henry D, Lexchin L. The pharmaceutical industry as a medicine provider. Lancet 2002; 360:1590-5.

2 Jack A. Novartis chief in warning on cheap drugs. Financial Times 2006 Sept 29.

doi 10.1136/bmj.39055.610764.47

\section{Introduction}

You probably know nothing of this extraordinary late Victorian and Edwardian age surgeon, but you should. Horsley contributed on so many different fronts: pioneering neurosurgeon, ardent experimenter, medical politician, social reformer, and author. If you ever need a doctor as a role model, a medical figure of international importance who was also a vocal social conscience, look no further.

By the age of 29, Horsley was a fellow of the Royal Society and had become the first surgeon in the world appointed to a hospital post as a "brain surgeon," with an impressive series of operative firsts to his name. He had confirmed the cause of rabies and helped to abolish the disease from the United Kingdom, and he had researched and published widely on many anatomical and physiological topics.

By his early death at 59, he had reformed the British Medical Association (BMA), Medical Defence Union (MDU), and the General Medical Council (GMC). He had also attempted and failed to reform the Royal College of Surgeons of England (no change there). He had espoused many radical socialist causes, pushing a somewhat reluctant medical establishment into supporting National Insurance, and making himself thoroughly unpopular supporting such issues as votes for women.

\section{A brief historical overview}

Horsley was born into London's artistic aristocracy in 1857. His father was a painter, a royal academician, who invented the Christmas card in 1843. His grandfather was a composer; his aunt inspired the composer Felix Mendelssohn. The house where he was born, in Camden Hill, Kensington, was a small artist's colony: artists Holman Hunt and Edward Lear, the water colourist who taught Queen Victoria, lived there. Horsley was named by the Queen, who became his godmother. He shared his birthday with her youngest child, Princess Beatrice.

By the time he entered London's University College Hospital (UCH) as a medical student, medicine and particularly surgery were at a turning point. The effects of ether had already been demonstrated in 1846 and Lister had described his antiseptic principles, although in the late 1870 s they were not universally accepted. Two of Horsley's relatives taught at UCH. One, Marcus Beck, made Horsley a disciple of Listerian principles.

At $\mathrm{UCH}$, he stood out. A vigorous and persuasive debater, he remained furiously argumentative throughout his life. He was already fervently against smoking and alcohol. He won many prizes, particularly in anatomy, and published several papers. Restless and energetic, with a head he described as "boiling with ideas," he qualified in 1881.

At the nearby National Hospital in Queen Square physicians were laying the foundations of modern neurology, among them Sir William Gowers,

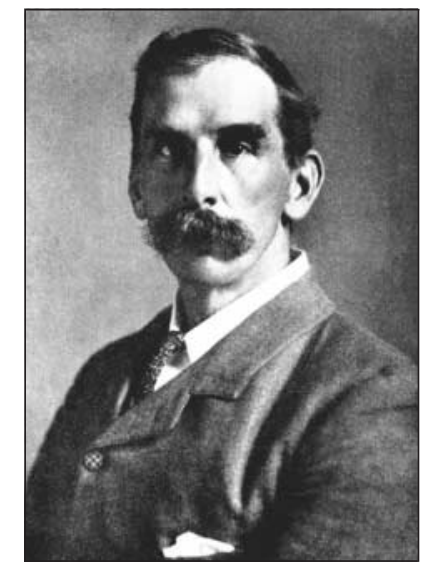

Sir Victor Horsley, FRS (1857-1916) 